\title{
Erratum to: Stop spoon dosing: milliliter instructions reduce inclination to spoon dosing
}

Koert van Ittersum ${ }^{1 *}$ and Brian Wansink ${ }^{2}$

\section{Erratum to: BMC Res Notes (2016) 9:33 DOI 10.1186/s13104-015-1809-1}

Unfortunately, the original version of this article [1] contained an error. The following sentence was incorrectly included in the Methods section, "All participants completed a consent form to participate in this research."

The third paragraph in the Methods section should have read, "The last sentence of the consent form read "By answering the survey questions you have agreed to be a participant in this study". To determine if teaspoon units in dose recommendations bias patient choice of measuring device for dispensing over-the-counter medicine, 194 university students (118 male; mean age, 20.6 years [SD, 1.5]) participated in a for-credit, between-subject design study.

\begin{abstract}
Author details
${ }^{1}$ Faculty of Economics and Business, University of Groningen, Nettelbosje 2, 9747 AE Groningen, The Netherlands. ${ }^{2}$ Cornell University, 15 Warren Hall, Ithaca, NY 14853-7801, USA.
\end{abstract}

The online version of the original article can be found under doi:10.1186/s13104-015-1809-1.

Received: 2 February 2016 Accepted: 8 February 2016 Published online: 14 March 2016

\section{Reference}

1. van Ittersum K, Wansink B. Stop spoon dosing: milliliter instructions reduce inclination to spoon dosing. BMC Res Notes. 2016;9:33.

\footnotetext{
*Correspondence: k.van.ittersum@rug.nl

${ }^{1}$ Faculty of Economics and Business, University of Groningen, Nettelbosje 2, 9747 AE Groningen, The Netherlands
}

Full list of author information is available at the end of the article 